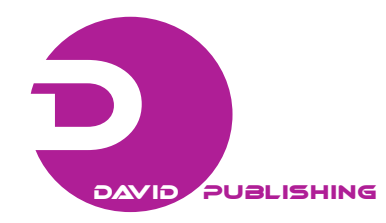

\title{
The Polyhexamethyleneguanidine Stimulation of Seeds Growing and Cell Proliferation
}

\author{
Lysytsya Andrij ${ }^{1}$, Lyco Sergij ${ }^{2}$ and Portuhaj Oksana ${ }^{2}$ \\ 1. West Polissya Agriculture Institute of National Academy of the Agrarian Sciences of Ukraine, Rivne 33028, Ukraine \\ 2. Rivne State University for Humanities, Rivne 33028, Ukraine
}

Received: August 20, 2013 / Accepted: September 27, 2013 / Published: October 25, 2013.

\begin{abstract}
Oligomer guanidines are highly efficient biocides against a broad spectrum of microorganisms. However, their stimulatory effects have not been studied yet. Our data allow us to expect the presence of growing stimulatory action for polyhexamethyleneguanidine (PHMG) under determined conditions. We investigated the action of the member of the polyguanidine family of biocides, PHMG on seeds growing. The comparative analysis of PHMG action was carried out on seeds of wheat, pea, rye, beet and maize. It was shown that of all PHMG salts tested only PHMG chloride and PHMG succinate could stimulate the growing of seeds. PHMG was also capable to increase their germination and vigor. The action on seeds of PHMG mixtures with inorganic salts (microelements) has also been examined. Amongst the drugs tested with a wide variety of ingredients the best stimulatory properties were proven for the composition of PHMG and succinic acid with boron, zinc, cobalt and magnesium. Most efficient growth stimulation was achieved after 15-minutes pre-sowing soaking of seeds of peas and beets. The stimulatory concentrations of PHMG were falling within the range of 0.001 to $0.5 \%$. Thus, the salts of PHMG can either depress or stimulate living organisms (including seeds) depending on PHMG concentration and anionic composition. The stimulation can be achieved by the non-specific adaptation of the cells (stress). In this case the stimulation is determined by the changes in the plasma membrane of the cell after adsorption of PHMG. The polycation of PHMG binds strongly with phosphoglycerides. Some lipids withdraw from participation in cellular processes. The acceleration the of new lipids synthesis and membrane-bound enzymes is likely to occure in the cell. The acceleration of new lipids synthesis and membrane-bound enzymes is likely to occur in the cell.
\end{abstract}

Key words: Polyhexamethyleneguanidine, stimulation effect, seeds growing.

\section{Introduction}

Polymeric

guanidines,

including polyhexamethyleneguanidine (PHMG) are usually used for disinfection or as antiseptics. PHMG (Fig. 1) has good antibacterial, antiviral, antifungal and other characteristics.

Excellent toxic profile of the polymeric guanidines (PHMG) and biguanides (PHMB), their lack of skin irritation, and oral tolerance allow one to widely deploy them, especially PHMB, in clinical applications such as treatment of Acanthamoeba keratinitis [1] as general disinfecting agents in the food industry, for the

Corresponding author: Lysytsya Andrij, Ph.D., associate professor, research fields: biophysics and agriculture. E-mail: lysycya@ukr.net. disinfection of swimming pools and other buildings [2, 3]. In Russia and Ukraine, disinfecting compositions based on the polymeric guanidines have found wide uses in hospitals, food industry, agriculture, wood and buildings protection, restoration of buildings, veterinary medicine [4]. Antimicrobial polymer systems, including guanidines, were surveyed by many researchers [5-7].

The mode of biocide action of PHMG has not been studied in full. Probably, it is similar to PGMB. Cationic polyelectrolyte salts of PGMB interact with membrane phospholipids of the cell. Many authors [8-11] had studied mechanisms of interaction of PGMB with Escherichia coli and the model of bilayer membrane of the microbial cell. PHMB was shown to 


$$
\left[\begin{array}{r}
-\left(\mathrm{CH}_{2}\right)_{6}-\mathrm{NH}-\mathrm{C}-\mathrm{NH}- \\
\mathrm{NH} \cdot \mathrm{HCl}
\end{array}\right]_{\mathrm{n}}
$$

Fig. 1 Monomer of the molecule of PHMG chloride.

cause domain formation of the acidic phospholipids of the plasma membrane (PM) in the vicinity of the adsorption site and to impair the integrity of the outer membrane of Gram-negative bacteria E. coli. It is important that the extent of membrane disruption is shown to increase with the growth of polymer length (from two links to greater than ten) [8]. Antibacterial activity of PHMG also depends on molecular weight or growth of polymer length $[12,13]$ and anion composition [4].

The sequence of events during PHMB interaction with the cell envelope of $E$. coli was proposed as follows: (1) there is rapid attraction of PHMB towards the negatively charged bacterial cell surface with strong and specific adsorption to phosphate-containing compounds; (2) the integrity of the outer membrane is impaired and PHMB adheres to the inner membrane; (3) binding of PHMB to phospholipids occurs with the increase in inner membrane permeability $\left(\mathrm{K}^{+}\right.$loss) accompanied by bacteriostatic; and (4) complete loss of membrane function follows by the precipitation of intracellular constituents and bactericidal effect [7-11, 14-17].

One and ditto material at different concentration are known to be either a poison or a medicine. On one hand, we have shown a positive effect of PHMB in the polihexanide on the proliferation of human keratinocytes at the concentrations of $2 \times 10^{-5} \%-2 \times$ $10^{-4} \%$. On the other hand, higher concentrations of polihexanide inhibited cell proliferation or were directly cytotoxic to the tested cell types in vitro [18]. Apart from that, polihexanide does not inhibit the re-epithelialization process at second-degree burns treatment and exhibits good antiseptic effect [19].

In our studies PHMG salts have affected growing of the primary culture of fibroblasts of the chicken embryo and interweaved culture of the trachea cells of calf [20]. PHMG could also hold up or stimulate the proliferation activity of trachea cells. Under $15 \mathrm{~min}$. preliminary exposure PHMG chloride was determined to slow down the proliferation activity at a concentration of $10^{-8} \%-10^{-7} \%$, while PHMG succinate at a concentration of $10^{-9} \%-10^{-7} \%$ accelerated the proliferation activity of fibroblasts. Hence, the best influence upon the growth of monolayer of the trachea cells was achieved at $10^{-7} \%$ of PHMG chloride and $10^{-8} \%$ of PHMG succinate.

The study of the PHMG action on samplings of fish Poecilia reticulata has shown that $10^{-7}-10^{-6} \%$ of PHMG increased the specific growing velocity factor by more than $60 \%$ in 7 days time as compared with the control [21]. In 14 days, the growth rate that includes the specific velocity of the growing, efficiency conversion of stern and optimum factors has slowed down still exceeding the growth rates of control. The authors suggest that the stimulatory effect is connected with adaptation syndrome (stress) and finally must be terminated by the phase of the exhaustion (progressing toxicosis). It should be noted that in this instance the preparation affected sapling fish constantly during the whole time of the experiment.

PHMG is also known to stimulate growing of the fungus Aspergillus niger at the concentration of $1 \times$ $10^{-5} \%$. Conversely, PHMG can reduce this growth at the larger concentration of $2 \times 10^{-5} \%$ [22].

This provides enough grounds to expect that under certain conditions the pretreatment of the seeds with PHMG can stimulate the seeds growing. For instance, Russian researchers processed wheat seeds by $0.1 \%-1.0 \%$ PHMG solution before sowing. In this case, PHMG not only protected the seeds from fungus (Alternarium, Penicillum, Mucor, Fusarium) but was also capable of stimulating the germination of seeds [23].

Thus, in this study we represent and discuss the results of the PHMG salts action on the plant seeds. 


\section{Materials and Methods}

\subsection{Chemicals}

The salts of PHMG chloride ( $\mathrm{HCl})$, PHMG succinate (HOOC- $\left.\mathrm{C}_{2} \mathrm{H}_{4}-\mathrm{COOH}\right)$, $\mathrm{PHMG}$ maleate $\left(\mathrm{HOOC}-\mathrm{C}_{2} \mathrm{H}_{2}-\mathrm{COOH}\right)$ and $\mathrm{PHMG}$ valerate $\left(\mathrm{C}_{4} \mathrm{H}_{9} \mathrm{COOH}\right)$ were kindly provided by «Termite» (Rivne, Ukraine). The PHMG was the mixture of its oligomers with $n$ ranging from 2 to 20 and a mean value of 10 . We used the water solutions of succinic acid $\mathrm{HOOC}-\mathrm{C}_{2} \mathrm{H}_{4}-\mathrm{COOH}$, boron acid $\mathrm{H}_{3} \mathrm{BO}_{3}$, salts $\mathrm{ZnSO}_{4} \cdot 7 \mathrm{H}_{2} \mathrm{O}, \quad \mathrm{CoSO}_{4} \cdot 7 \mathrm{H}_{2} \mathrm{O}$ and $\mathrm{MnCl}_{2} \cdot 4 \mathrm{H}_{2} \mathrm{O}$ (MERCK KGaA). The water solutions of PHMG salts were used at the concentrations ranging from $1 \times 10^{-4}$ to $1.0 \%$ or $1.0 \mathrm{mg} / 1$ to $10 \mathrm{~g} / \mathrm{l}(\mathrm{pH} 5-7)$.

Vegetable material. Seeds of wheat (Triticum aestivum) variety "Rannya yara, 93", pea (Pisum sativum) "Alpha", rye (Secale cereale) "Kharkivske, 98", beet (Beta vulgaris) "Ursus poly" and maize (Zea mays) sugar variety "Brusnycia rannya".

\subsection{Methods}

Germination, germination energy, the size of the root (L) and the length of the stem (1) were determined for all type of seeds by the standard methods [24]. Germination (\%) represents the ratio between the number of germinated seeds and the total number of seeds used for germination. The germination energy or vigor is simultaneity of germination in a relatively short period. Seeds were soaked in aqueous solutions of drugs for 15-20 min time. Thereafter, they were dried gently on filter paper and placed in petri dish. Seeds were germinated on moistened filter pads of paper and cotton wool or rolls of filter paper. The vigor of seeds for the maize was determined on the 3rd day. The germination of the maize seeds was determined on the 7 th day. The vigor and germination was determined on the 3rd and the 7th days for the rye seeds, for the wheat, on the 4th and the 8th days, for the beet, on the 5 th and the 10th days, for the pea, on the 3rd and 7th days. The size of the root (L) and the length of the stem (1) were determined at the same day and the same week with the germination of seeds. The temperature varied from 12 to $22{ }^{\circ} \mathrm{C}$, the lighting was natural and artificial, and the moisture of the air was 70\%-90\%. Tables 1-4 represent the average result of several experiments $(n \geq 3)$.

\section{Results and Discussion}

Table 1 shows the average values of the growth indicators of rye "Kharkivske-98" for all tested concentrations of various PHMG salts from $10^{-4}$ to 1.0\%. PHMG succinate and PHMG chloride showed the best results. For the seeds of other plants, the results were similar. The dimension of the roots (L) and the length of the stem (1) did not increase.

Good results obtained with PHMG succinate preparation could be partly explained by the presence of succinic acid in it as succinic acid itself may have a positive influence on seed germination and crop yields. Control experiments were carried out on the seeds of peas. It turned out that the germination of seeds treated with PHMG succinate at the concentrations falling within the range between $0.0001 \%-0.0050 \%$ to $25 \%-30 \%$ was higher than that measured on seeds treated by the same concentrations of succinic acid.

Table 1 The influence of different PHMG salts on the growing factors of rye seeds.

\begin{tabular}{lllll}
\hline Salts & $\begin{array}{l}\text { The germination energy } \\
\text { (vigor)/control (\%) }\end{array}$ & $\begin{array}{l}\text { The germination/control } \\
(\%)\end{array}$ & $\begin{array}{l}\text { L, mm/control, \% (in 7 } \\
\text { days) }\end{array}$ & 1 mm/control,\% (in 7 days) \\
\hline PHMG chloride & 103.9 & 102.1 & $26.0 / 85.3$ & $21.0 / 91.2$ \\
PHMG succinate & 110.7 & 108.5 & $24.1 / 79.0$ & $22.4 / 97.2$ \\
PHMG maleate & 94.9 & 100.7 & $20.5 / 67.1$ & $21.1 / 91.9$ \\
PHMG valerate & 90.0 & 92.8 & $21.3 / 69.8$ & $20.8 / 90.5$ \\
control $\left(\mathrm{H}_{2} \mathrm{O}\right)$ & 100.0 & 100.0 & $30.5 / 100.0$ & $23.0 / 100.0$ \\
\hline
\end{tabular}

$\mathrm{P}>0.95$. 
The germination was not sufficient remaining within the limits of $10 \%$. The differences obtained with the other PHMG concentrations were negligible. The observed increase in the vigor of peas may result from the action of PHMG salt. The efficacy of PHMG chloride mixture with succinic acid was two times lower than that of PHMG succinate.

A lot better results were obtained with the mixtures of PHMG salts and inorganic salts required for normal growth of seeds. The selection of the salts of microelements was based on the characteristics of our local soils. The soils from geochemical zones of Western Ukraine (Rivnenska, Volynska, Ivano-Frankivska, Chernivetska and other Regions) contain insufficient number of digestible forms of microelements I, Co, Zn, Mn. Moreover, the soil samples from Rivne and Volyn regions are poor in $\mathrm{Cu}$ and $\mathrm{B}$ [25]. The deficiency of these microelements inhibits the plants growth and further increase of the crops picked up in these areas. Therefore, the use of PHMG for pre-sowing treatment is more appropriate in combination with the introduction of micronutrients. However, metal ions $\mathrm{Cu}^{2+}, \mathrm{Ni}^{2+}, \mathrm{Zn}^{2+}, \mathrm{Co}^{2+}, \mathrm{Cr}^{3+}, \mathrm{Fe}^{3+}$, $\mathrm{Pb}^{2+}, \mathrm{Hg}^{2+}, \mathrm{Mn}^{2+}$ can displace proton from protonated imino groups of the polymer and form persistent complex compounds with PHMG [4]. The properties of PHMG change. Moreover, ions of $\mathrm{Cu}^{2+}$ with PHMG form insoluble complexes. The original stimulator of seeds growth we used contained following components: PHMG succinate (or PHMG chloride $+0.5 \%$ succinic acid) $-10 \%$ (mass), $\mathrm{ZnSO}_{4}(2 \%), \mathrm{CoSO}_{4}(2 \%), \mathrm{MnCl}_{2}$ (1\%), $\mathrm{H}_{3} \mathrm{BO}_{3}(0.5 \%)$ and water (pH 5-6). The comparative analysis of the stimulatory action of pure PHMG succinate (I) and its mixture with the salts of microelements (II) has proved that their vigor was not significantly different (Table 2), even though it was almost two times higher than control $\left(\mathrm{H}_{2} \mathrm{O}\right)$. The germination of seeds, the size of the root $(\mathrm{L})$ and the length of the stem (1) increase significantly when PHMG succinate is composed with the salts of microelements (II).

In the other set of experiments we have compared the efficiency of two preparations, PHMG succinate $\left(1 \times 10^{-4}-1.0 \%\right)$ with the salts of microelements and the mixture of succinic acid at the same concentration with the salts of microelements. The vigor and the germination of pea seeds treated with the first preparation increased by $20 \%-25 \%$ and by $25 \%-30 \%$, correspondingly as compared with those treated with the second preparation.

Table 2 The stimulatory action of PHMG succinate and its mixture with the salts of microelements on the growing factors of pea seeds.

\begin{tabular}{|c|c|c|c|c|c|c|c|c|c|c|c|c|}
\hline \multirow{3}{*}{$\begin{array}{l}\text { The } \\
\text { concentrat } \\
\text { ions of } \\
\text { PHMG } \\
(\%)\end{array}$} & \multicolumn{6}{|c|}{ I. PHMG succinate } & \multicolumn{6}{|c|}{ II. PHMG succinate + salts of microelements } \\
\hline & \multirow{2}{*}{$\begin{array}{l}\text { The } \\
\text { germination } \\
\text { energy } \\
\text { (vigor)/control } \\
\text { ratio (\%) }\end{array}$} & \multirow{2}{*}{$\begin{array}{l}\text { The } \\
\text { germinatio } \\
\text { n/control } \\
\text { ratio (\%) }\end{array}$} & \multicolumn{2}{|c|}{$\mathrm{L}$ in 13 days } & \multicolumn{2}{|c|}{1 in 13 days } & \multirow{2}{*}{$\begin{array}{l}\text { The } \\
\text { germination } \\
\text { energy } \\
\text { (vigor)/control } \\
\text { ratio (\%) }\end{array}$} & \multirow{2}{*}{$\begin{array}{l}\text { The } \\
\text { germinatio } \\
\mathrm{n} / \text { control } \\
\text { ratio }(\%)\end{array}$} & \multicolumn{2}{|c|}{$\mathrm{L}$ in 13 days } & \multicolumn{2}{|c|}{1 in 13 days } \\
\hline & & & $\mathrm{mm}$ & $\begin{array}{l}\% \text { vs. } \\
\text { control } \\
\text { ratio }\end{array}$ & $\mathrm{mm}$ & $\begin{array}{l}\% \text { vs. } \\
\text { control } \\
\text { ratio }\end{array}$ & & & $\mathrm{mm}$ & $\begin{array}{l}\% \text { vs. } \\
\text { control } \\
\text { ratio }\end{array}$ & $\mathrm{mm}$ & $\begin{array}{l}\% \text { vs. } \\
\text { control } \\
\text { ratio }\end{array}$ \\
\hline 1.0 & 125.5 & 62.5 & 13.7 & 62.8 & 5.2 & 81.3 & 121.2 & 141.5 & 17.8 & 81.7 & 8.3 & 129.7 \\
\hline 0.5 & 150.1 & 137.5 & 16.7 & 76.6 & 6.5 & 101.6 & 80.3 & 130.0 & 19.6 & 89.9 & 7.1 & 110.9 \\
\hline 0.1 & 175.6 & 87.5 & 16.3 & 74.8 & 4.9 & 76.6 & 181.8 & 183.4 & 25.2 & 115.6 & 8.7 & 135.9 \\
\hline 0.05 & 175.2 & 56.3 & 24.6 & 112.8 & 8.6 & 134.4 & 125.8 & 216.7 & 26.8 & 122.9 & 8.8 & 137.5 \\
\hline 0.01 & 225.3 & 75.0 & 24.7 & 113.3 & 7.7 & 120.3 & 257.6 & 225.0 & 31.6 & 145.0 & 9.1 & 142.2 \\
\hline 0.005 & 250.0 & 100.0 & 20.9 & 95.9 & 6.1 & 95.3 & 212.1 & 200.0 & 22.8 & 104.6 & 9.7 & 151.6 \\
\hline 0,001 & 325.5 & 143.8 & 22.0 & 100.9 & 8.6 & 134.4 & 348.5 & 300.0 & 32.9 & 150.9 & 11.4 & 178.1 \\
\hline 0,0001 & 125.3 & 100.0 & 20.3 & 93.1 & 5.5 & 85.9 & 242.4 & 200.0 & 31.3 & 143.6 & 9.7 & 151.6 \\
\hline average & 194.1 & 95.5 & - & 91.3 & - & 103.7 & 196.2 & 199.6 & - & 119.3 & - & 142.2 \\
\hline $\begin{array}{l}\text { control } \\
\left(\mathrm{H}_{2} \mathrm{O}\right)\end{array}$ & 100.0 & 100.0 & 21.8 & 100.0 & 6.4 & 100.0 & 100.0 & 100.0 & 21.8 & 100.0 & 6.4 & 100.0 \\
\hline
\end{tabular}

$\mathrm{P}>0.95$. 
The comparative analysis of stimulatory actions of the mixture of PHMG succinate with the salts of microelements and the mixture of PHMG chloride with the salts of microelements has shown that the secondcomposition better stimulates the vigor and germination while the overall size of the root (L) and the length of the stem (1) remain almost indistinguishable from controls. The experimental results for beet seeds are represented in Table 3 .

The seeds of the maize were processed by the mixture of succinic acid with the salts of microelements and PHMG succinate with the salts of microelements at the same concentration of the salts. We have defined that the second composition stimulates the vigor by $30 \%-40 \%$ and germination by $4 \%-10 \%$. The length of the sprouts and roots increased by $30 \%-60 \%$ (Table 4 ). The optimum concentration of PHMG was 0.01\%-0.001\%.

Thus, the obtained results proved that the PHMG salt can stimulate the seed germination. PHMG succinate and its composition with minerals salts exhibited the best results of the all other PHMG salts tested. The use

Table 3 The action of PHMG chloride mixture with the salts of microelements and PHMG succinate with the microelements compared with the growing factors of the beet seeds.

\begin{tabular}{|c|c|c|c|c|c|c|c|c|c|c|c|c|}
\hline \multirow{3}{*}{$\begin{array}{l}\text { The } \\
\text { concentrat } \\
\text { ions of } \\
\text { PHMG } \\
(\%)\end{array}$} & \multicolumn{6}{|c|}{ PHMG chloride + salts of microelements } & \multicolumn{6}{|c|}{ PHMG succinate + salts of microelements } \\
\hline & \multirow{2}{*}{$\begin{array}{l}\text { The } \\
\text { germination } \\
\text { energy } \\
\text { (vigor)/control } \\
\text { ratio (\%) }\end{array}$} & \multirow{2}{*}{$\begin{array}{l}\text { The } \\
\text { germinatio } \\
\text { n/control } \\
\text { ratio (\%) }\end{array}$} & \multicolumn{2}{|c|}{$\mathrm{L}$ in 10 days } & \multicolumn{2}{|c|}{1 in 10 days } & \multirow{2}{*}{$\begin{array}{l}\text { The } \\
\text { germination } \\
\text { energy } \\
\text { (vigor)/control } \\
\text { ratio }(\%)\end{array}$} & \multirow{2}{*}{$\begin{array}{l}\text { The } \\
\text { germinatio } \\
\text { n/control } \\
\text { ratio (\%) }\end{array}$} & \multicolumn{2}{|c|}{$\mathrm{L}$ in 10 days } & \multicolumn{2}{|c|}{1 in 10 days } \\
\hline & & & $(\mathrm{mm})$ & $\begin{array}{l}\% \text { vs. } \\
\text { control } \\
\text { ratio }\end{array}$ & $(\mathrm{mm})$ & $\begin{array}{l}\% \text { vs. } \\
\text { control } \\
\text { ratio }\end{array}$ & & & $(\mathrm{mm})$ & $\begin{array}{l}\% \text { vs. } \\
\text { control } \\
\text { ratio }\end{array}$ & $(\mathrm{mm})$ & $\begin{array}{l}\% \text { vs. } \\
\text { control } \\
\text { ratio }\end{array}$ \\
\hline 1.0 & 200.0 & 250.0 & 13.9 & 53.3 & 18.4 & 44.2 & 327.3 & 333.4 & 9.0 & 34.5 & 30.1 & 72.6 \\
\hline 0.5 & 309.1 & 333.4 & 14.5 & 55.8 & 34.7 & 83.6 & 356.4 & 383.4 & 11.7 & 44.9 & 36.7 & 88.3 \\
\hline 0.1 & 163.6 & 166.7 & 48.2 & 185.2 & 46.0 & 110.8 & 290.9 & 300.0 & 34.2 & 131.4 & 49.3 & 118.8 \\
\hline 0.05 & 218.2 & 233.4 & 41.3 & 158.9 & 51.5 & 124.1 & 200.0 & 200.0 & 29.9 & 115.0 & 39.8 & 95.8 \\
\hline 0.01 & 163.6 & 150.0 & 39.7 & 152.5 & 51.5 & 124.1 & 254.5 & 233.3 & 32.9 & 126.4 & 50.7 & 122.2 \\
\hline 0.005 & 127.2 & 133.3 & 34.5 & 132.7 & 50.2 & 121.0 & 218.2 & 250.0 & 31.9 & 122.5 & 51.0 & 122.9 \\
\hline 0.001 & 181.8 & 216.7 & 37.2 & 143.1 & 52.2 & 125.7 & 145.5 & 150.0 & 20.4 & 78.2 & 28.9 & 69.6 \\
\hline 0.0001 & 127.2 & 150.0 & 33.4 & 128.2 & 43.7 & 105.2 & 326.8 & 316.7 & 30.4 & 116.7 & 51.0 & 122.9 \\
\hline average & 187.3 & 204.2 & - & 126.2 & - & 104.8 & 265.0 & 270.9 & - & 96.2 & - & 101.6 \\
\hline $\begin{array}{l}\text { control } \\
\left(\mathrm{H}_{2} \mathrm{O}\right)\end{array}$ & 100.0 & 100.0 & 26 & 100.0 & 41.5 & 100.0 & 100.0 & 100.0 & 26 & 100.0 & 41.5 & 100.0 \\
\hline
\end{tabular}

$\mathrm{P}>0.95$.

Table 4 The stimulatory action of the mixture of succinic acid with the salts of microelements and the mixture of PHMG succinate with the microelements vs. the growing factors of the maize seeds.

\begin{tabular}{|c|c|c|c|c|c|c|c|c|c|c|c|c|}
\hline \multirow{3}{*}{$\begin{array}{l}\text { The } \\
\text { concentratio } \\
\text { ns of PHMG } \\
(\%)\end{array}$} & \multicolumn{6}{|c|}{ Succinic acid + salts of microelements } & \multicolumn{6}{|c|}{ PHMG succinate + salts of microelements } \\
\hline & \multirow{2}{*}{$\begin{array}{l}\text { The } \\
\text { germination } \\
\text { energy } \\
\text { (vigor)/control } \\
\text { ratio (\%) }\end{array}$} & \multirow{2}{*}{$\begin{array}{l}\text { The } \\
\text { germinat } \\
\text { ion/contr } \\
\text { ol ratio } \\
(\%)\end{array}$} & \multicolumn{2}{|c|}{$\mathrm{L}$ in 7 days } & \multicolumn{2}{|c|}{1 in 7 days } & \multirow{2}{*}{$\begin{array}{l}\text { The } \\
\text { germination } \\
\text { energy } \\
\text { (vigor)/control } \\
\text { ratio (\%) }\end{array}$} & \multirow{2}{*}{$\begin{array}{l}\text { The } \\
\text { germinatio } \\
\text { n/control } \\
\text { ratio (\%) }\end{array}$} & \multicolumn{2}{|c|}{$\mathrm{L}$ in 7 days } & \multicolumn{2}{|c|}{1 in 7 days } \\
\hline & & & $(\mathrm{mm})$ & $\begin{array}{l}\% \text { vs. } \\
\text { control } \\
\text { ratio }\end{array}$ & $(\mathrm{mm})$ & $\begin{array}{l}\% \mathrm{vs}, \\
\text { control } \\
\text { ratio }\end{array}$ & & & $(\mathrm{mm})$ & $\begin{array}{l}\% \text { vs. } \\
\text { control } \\
\text { ratio }\end{array}$ & $(\mathrm{mm})$ & $\begin{array}{l}\% \text { vs. } \\
\text { control } \\
\text { ratio }\end{array}$ \\
\hline 0.5 & 125.4 & 109.3 & 61.0 & 70.9 & 69.0 & 113.1 & 132.6 & 100.5 & 62.0 & 72.1 & 58.0 & 95.0 \\
\hline 0.1 & 116.9 & 98.3 & 73.0 & 84.9 & 45.0 & 73.8 & 117.6 & 103.0 & 66.0 & 76.7 & 67.0 & 109.8 \\
\hline 0.01 & 124.6 & 101.8 & 72.0 & 83.7 & 53.0 & 86.9 & 144.7 & 110.5 & 135.0 & 156.9 & 81.0 & 132.8 \\
\hline 0.001 & 109.0 & 89.3 & 96.0 & 111.6 & 70.0 & 114.7 & 132.5 & 104.3 & 117.0 & 136.0 & 80.0 & 131.1 \\
\hline 0.0001 & 100.9 & 90.5 & 96.0 & 111.6 & 86.0 & 140.9 & 120.4 & 93.8 & 92.0 & 106.9 & 79.0 & 129.5 \\
\hline average & 115.4 & 97.8 & 79.6 & 92.5 & 64.6 & 105.9 & 129.6 & 102.4 & 94.4 & 109.7 & 73.0 & 119.6 \\
\hline $\begin{array}{l}\text { control } \\
\left(\mathrm{H}_{2} \mathrm{O}\right)\end{array}$ & 100.0 & 100.0 & 86.0 & 100.0 & 61.0 & 100.0 & 100.0 & 100.0 & 86.0 & 100.0 & 61.0 & 100.0 \\
\hline
\end{tabular}


of separate aqueous solutions of PHMG chloride, aqueous mixtures of the salts of microelements, the composition of PHMG chloride and succinic acids was less efficient. The treatment of beet seeds complex preparation that consists of PHMG succinate, boric acid and inorganic salts of zinc, cobalt, manganese increased the vigor by $80 \%-90 \%$ and germination by $100 \%$. Average results of all concentrations of this composition for pea also gave rise to the growth by a factor of $\sim 2$. The good results were also obtained for the maize, wheat and rye. But, more importantly was that PHMG salts have positive influence upon the growing factors of seeds. Moreover, PHMG applied with the purpose of growth stimulation also partially disinfected the seeds. The optimal concentration of PHMG necessary to stimulate the seed germination ( 0.001-0.5\%) was also bactericidal and fungistatic.

The mechanism of stimulatory action of PHMG is not quite comprehensible yet. We can assume that it is related to the properties of surfactants, thus changing the permeability of plasma membranes.

Anyway, PHMG action is associated with the stimulation of proliferation activity of the cells. It also should be noted that the constant exposure of the target cells to PHMG at the concentration of $0.2 \mathrm{mg} / \mathrm{l}(2 \times$ $10^{-5} \%$ ) decreased the photosynthesis and increased the amount of plant cells deaths at the PHMG concentration of $0.01 \%$. Thus, it can be assumed that the PHMG, when it chronic action, are stimulating seed plants in ranging concentrations $10^{-9}-10^{-6} \%$ as it was in the case of animal cells [20]. Stimulatory concentrations of PHMG succinate are higher than those of PHMG chloride.

The PHMG induced stimulation can be caused by the non-specific adaptation of the cells to a stress as in the case of fish P. Reticulata [21]. The changes that occur in the plasma membrane of the cell after PHMG polycation adsorption are the major cause of PHMG induced stimulation. The PHMG adsorption is likely to change the surface charge of the cell membrane and the transmembrane potential, membrane permeability to water, small ions, mobility of phospholipids and regular activity of enzymes. For instance, PHMG is capable of inhibiting the catalase and superoxidedismutase. In some microorganisms like Candida tropicalis or Salmonella typhimurium the PGMG mode of action is similar at the concentration of $10^{-3} \%$ and $10^{-5} \%$, correspondingly [26]. The change of plasma membrane properties caused by PHMG adsorption is enhanced by the increase of hydrogen peroxide and superoxide concentration due to the antioxidative effect of catalase and superoxidedismutase. Aggressive $\mathrm{H}_{2} \mathrm{O}_{2}$ and $: \mathrm{O}_{2}{ }^{-}$may even facilitate membrane damage by interaction with unsaturated fatty acids of membrane lipids. Short time exposure to low (stimulus) PHMG concentrations reversibly inhibits these enzymes, whilst compensatory mechanisms of cells start liponeogenesis and the synthesis of new enzymes. PHMB is also able to affect expression of certain genes in E. coli, enzyme synthesis, etc. [27].

It also should be noted that instead of binding with acid phospholipids, only the polycation of PHMG also creates quite strong bonds with phosphoglycerides. For example, PHMG polycation is quick to adhere and change the ionic permeability of almost uncharged bilayer lipid membrane composed of phosphatidylcholine-cholesterol (weight ratio of 2:1) at the concentration of $2 \times 10^{-5} \%$ or higher [28]. The content of cell phospholipids changes [9]. The removal of some plasma membrane phospholipids from active participation in cellular processes forces the synthesis of new lipids and possibly membrane-bound enzymes. This is likely to reduce the duration of regular cellular cycle. Thus, the adaptive mechanisms of the cell also triggers the synthesis of new polar lipids in case of PHMG induced stimulation of $A$. niger [22]. The acceleration of phospholipid synthesis under certain conditions stimulates mitosis.

It should be noted that PHMG is environmentally friendly and susceptible to biodegradation. For example, Pseudomonas putida was capable of 
extensive growth with 1,6-diguanidinohexane as a sole nitrogen source. This takes place at complete removal of guanidine groups from culture medium within 2 days and concomitant formation of unsubstituted urea, which in turn was also utilised [29]. Moreover, nitrogen-fixing bacteria of the soil are quite resistant to PHMG action [4].

\section{Conclusions}

Thus, the action of PHMG salts on seeds can be either depressing (biocide) or stimulating. The mode of action depends on the concentration and anionic composition of PHMG preparation. The preliminary treatment of seeds by polymeric derivatives of guanidine can increase germination of seeds and their vigor. This stimulation appears to be stochastic rather than deterministic because the length of roots and shoots of seedlings do not usually increase and sometimes even decrease. PHMG mixtures with inorganic salts (microelements) have shown good results. Amongst the drugs tested with variety of ingredients the best stimulating properties belongs to the composition of PHMG with succinic acid in combination with microelements boron, zinc, cobalt, magnesium. This drug has proved the best result at 15-minute pre-sowing soaking of seeds of peas and beets.

The discovered stimulatory effect is primarily associated with PHMG succinate or PHMG chloride. Even though, the stimulatory effect of the pure PHMG is relatively small it is possible that after additional research PHMG can be recommended for pre-treatment of seeds due to its disinfecting properties.

\section{References}

[1] D. Larkin, S. Kilvington, J. Dart Treatment of Acanthamoeba Keratitis with Polyhexamethylene Biguanide, Ophthalmology 99 (2) (1992) 185-191.

[2] S.S. Block, Disinfection, Sterilization and Preservation, 5th ed, Philadelphia: Lippincott Williams \& Wilkins, New York, 2001.

[3] P. Gilbert, A. McBain, An evaluation of the potential impact of the increased use of biocides within consumer products upon the prevalence of antibiotic resistance, Clinical Microbiology Reviews 16 (2003) 189-208.

[4] I. Vointseva, P. Gembitsky, Polyguanidines-disinfecting agents and multifunctional additives to composite materials, LKM, Moscow, 2009, p. 304. (in Russian)

[5] S. Worley, G. Sun, Biocidal polymers, Trends Polym. Sci. 4 (1996) 364-370.

[6] G. Afinogenov, E. Panarin, Antimicrobial Polymers, Gippokrat, St. Petersburg, 1993, p. 264. (in Russian)

[7] L. Timofeeva, N. Kleshcheva, Antimicrobial polymers: Mechanism of action, factors of activity, and applications, Appl. Microbiol. Biotechnol. 89 (2011) 475-492.

[8] P. Broxton, P. Woodcock, P. Gilbert, A study of the antibacterial activity of some polyhexamethylene biguanides towards Escherichia coli ATCC 8739, J. Appl. Bacteriol. 54 (3) (1983) 345-353.

[9] P. Broxton, P. Woodcock, M. Heatley, P. Gilbert, Interaction of some polyhexamethylene biguanides and membrane phospholipids in Escherichia coli, J. Appl. Bacteriol. 57 (1) (1984) 115-124.

[10] T. Ikeda, S. Tazuke, M. Watanabe, Interaction of biologically active molecules with phospholipid membranes: Part 1. Fluorescence depolarization studies on the effect of polymeric biocide bearing biguanide groups in the main chain, Biochim Biophys Acta. 735 (3) (1983) 380-386.

[11] T. Ikeda, A. Ledwith, C. Bamford, R. Hann, Interaction of a polymeric biguanide biocide with phospholipid membranes, Biochem. Biophys. Acta. 769 (1984) 57-66.

[12] M. Albert, P. Feiertag, H. Gertraud, Structure-activity relationships of oligoguanidines: Influence of counterion, diamine, and average molecular weight on biocidal activities, Biomacromolecules 4 (6) (2003) 1811-1817.

[13] D. Weia, Q. Maa, Y. Guana, Structural characterization and antibacterial activity of oligoguanidine (polyhexamethylene guanidine hydrochloride), Materials Science and Engineering 29 (6) (2009) 1776-1780.

[14] T. Franklin, G. Snow, Antiseptics, antibiotics and the cell membrane, Biochemistry of Antimicrobial Action, 3rd ed., Chapman \& Hall, London. 1981, pp. 58-78.

[15] G. McDonnell, A. Russell, Antiseptics and disinfectants: Activity, action, and resistance, Clinical Microbiology Reviews 12 (1) (1999) 147-179.

[16] J.Y. Maillard, Bacterial target sites for biocide action, J. Appl. Microbiol. Symp. Suppl. 92 (2002) 16-27.

[17] P. Gilbert, L. Moore, Cationic antiseptics: Diversity of action under a common epithet, J. Appl. Microbiol. 99 (2005) 703-715.

[18] C. Wieg, M. Abel, A. Kramer, Proliferation demand and biocompatibility of polihexanide, GMS hospital hygiene Inter Disciplinary, 2 (2) (2007), 
http://www.egms.de/en/journals/dgkh/2007-2/dgkh00007 6.shtml.

[19] G. Daeschlein, O. Assadian, J.C. Bruck, Feasibility and clinical applicability of polihexanide for treatment of second-degree burn wounds, Skin Pharmacol Physiol. 20 (6) (2007) 292-296.

[20] A. Lysytsya, P. Kryvoshya, PHMG salts stimulate the proliferation activity of cells, Scientific notes of Ternopil Pedagogical University, 4 (53) (2012) 21-26. (in Ukraine)

[21] V.S. Gavrikova, A.A. Ignatyuk, V.L. Chumak, Impact of polyhexamethyleneguanidine to bio-productive parameters of young fish, Scientific News NTU "KP" 3 (2010) 16-20. (in Ukraine)

[22] L.S. Kuznetsova, The mechanism of action of polyguanidine disinfectants, Meat Industry 4 (2001) 52. (in Russian)

[23] P. Gembitsky, K. Efimov, Protection of wheat against biological damage, Bread Products 11 (1999) 26-27. (in Russian)

[24] Agricultural Seeds, Methods for Determination of Quality, M.: Agropromizdat, 1991, p. 415. (in Russian)
[25] A. Lysytsya, M. Mandygra, M. Soroka, Zeolit-smektyte tufe of Rivne region, Biology aspects of use, Rivne: Volynski. Oberegy., 2005, p. 184. (in Ukraine)

[26] V.F. Marievsky, I.I. Danilenko, A.I. Baranov, Enhancement of epidemic and chemical safety of water as a problem of choosing the new reagents for disinfection, Preventive Medicine 3 (7) (2009) 53-62. (in Ukraine)

[27] M. Allen, G. White, A. Morby, The response of Escherichia coli to exposure to the biocide polyhexamethylene biguanide, Microbiology 152 (2006) 989-1000.

[28] A. Lysytsya, P. Kryvoshya, O. Shatursky, Effect of polyhexamethyleneguanidine hydrochloride to plasma membrane of chicken embryo fibroblasts and in artificial bilayer lipid membrane, Biotechnology 3 (2) (2010) 56-61. (in Ukraine)

[29] L. O'Malley, A. Collins, G. White, Biodegradability of end-groups of the biocide polyhexamethylene biguanide (PHMB) assessed using model compounds, Journal of Industrial Microbiology and Biotechnology 33 (8) (2006) 677-684. 